\title{
Female gametophyte development in Adesmia latifolia (Spreng.) Vog. (Leguminosae - Papilionoideae) $^{1}$
}

\author{
MARIA C.C. MOÇO ${ }^{2,3}$ and JORGE E.A. MARIATH ${ }^{2}$
}

(received: March 19, 2003; accepted: December 11, 2003)

\begin{abstract}
Female gametophyte development in Adesmia latifolia (Spreng.) Vog. (Leguminosae - Papilionoideae)). The female gametophyte has a monosporic origin and a Polygonum type development. The female gametophyte growth consumes a large part of the neighboring nucellar cells and, in the micropylar region, part of the nucellar epidermis and internal integument. The mature gametophyte is composed of only four cells due to the ephemeral characteristic of the antipodals. The synergids are pear-shaped cells with the formation of filiform apparatus. Their nuclei lie in the micropylar region and large vacuoles in the chalazal region, while the egg cell presents an opposite polarization. The central cell accumulates starch grains and the two polar nuclei approach the egg. Occasional development of two gametophytes was recorded. The closest to the micropyle develops fully, while the chalazal one remained in the tetranucleated stage. The embryological characters of A. latifolia are compared with those of other taxa within the Leguminosae, and the reproductive importance of multiple gametophyte formation for this species was discussed.
\end{abstract}

Key words - Adesmia, embryo sac, embryology, female gametophyte, Leguminosae

RESUMO - (Desenvolvimento do gametófito feminino em Adesmia latifolia (Spreng.) Vog. (Leguminosae - Papilionoideae)). O desenvolvimento do gametófito feminino é do tipo monospórico Polygonum. Durante o crescimento, o gametófito consome grande parte das células nucelares vizinhas e, na região micropilar, parte da epiderme nucelar e tegumento interno. O gametófito feminino maduro é composto por cinco núcleos e quatro células, pois as antípodas são efêmeras. As sinérgides são piriformes com formação de aparelho fibrilar. Essas apresentam o núcleo na região micropilar e grande vacúolo na região calazal, enquanto que a oosfera apresenta polarização contrária. A célula média armazena grãos de amido e os núcleos polares se aproximam do aparelho oosférico. Em alguns casos registrou-se o desenvolvimento de dois gametófitos, sendo que o mais próximo da micrópila se desenvolve completamente, enquanto que o calazal permanece no estádio tetranucleado. Foram feitas comparações taxonômicas entre os caracteres embriológicos dentro da família Leguminosae e foi discutida a importância reprodutiva da formação de gametófitos múltiplos para a espécie.

Palavras-chave - Adesmia, embriologia, gametófito feminino, Leguminosae, saco embrionário

\section{Introduction}

Variation in female gametogenesis in the angiosperms have been characterized mainly by cytokinesis after meiosis, polarity and the number of mitotic cycles (Willemse \& Van Went 1984, Haig 1990). In the Leguminosae family the monosporic development of the Polygonum type (Davis 1966, Prakash 1987) is the most common, but a few cases of bisporic have been recorded for Lupinus, Cytisus (Guignard 1881), Laburnum anagyroides Medik. (Rembert 1966), Wisteria chinensis DC. (Rembert 1967) and Pueraria lobata (Willd.) Ohwi (Rembert 1969). The monosporic

1. Parte integrante da Tese de Doutorado de M.C.C. Moço, no Programa de Pós-Graduação em Botânica da Universidade Federal do Rio Grande do Sul.

2. Universidade Federal do Rio Grande do Sul, Departamento de Botânica, Laboratório de Anatomia Vegetal, Av. Bento Gonçalves 9500, Prédio 43423, sala 206, 91501-970 Porto Alegre, RS, Brazil.

3. Corresponding author: chiaramoco@yahoo.com.br
Oenothera type was also recorded in Vigna unguiculata (L.) Walp. (Ojeaga \& Samyaolu 1970). Other exclusive types (Mirbella and Jacksonia) and their variations were described by Cameron \& Prakash (1994) in Australian endemic species of the Tribes Bossiaeeae and Mirbelieae.

Many studies described the megagametogenesis in angiosperms, but little attention has been given to the structural and cytological aspects of the female gametophyte. In the Leguminosae, different aspects like gametophyte lifetime, shape and size of individual cells and their wall specializations, and starch synthesis and storage, seems to be very important, not only for systematic comparisons, but also for the knowledge of fertilization process and embryo development.

The ovule ontogeny, as well as the megasporogenesis events were discussed in a previous paper Moço \& Mariath (2003). The objective of this work is to analyse the female gametophyte development in Adesmia latifolia (Spreng.) Vog. and its relationship within the family. 


\section{Material and methods}

Floral buds of Adesmia latifolia were collected from cultivated plants at the Agronomic Station of the Federal University of Rio Grande do Sul in the Eldorado do Sul city, RS. A voucher specimen was placed in ICN Herbarium (ICN 122710), Botany Department at the same university.

The pistils were fixed in glutaraldehyde $1 \%$ and formaldehyde 4\% (McDowell \& Trump 1976), in sodium phosphate buffer $0.1 \mathrm{M}, \mathrm{pH} 7.2$; dehydrated in ethanol and included in hydroxyethylmethacrylate (Gerrits \& Smid 1983). The blocks were sectioned at 3-4 $\mu \mathrm{m}$ with a Zeiss Mikron microtome. The sections were stained with Toluidine Blue $\mathrm{O}$ 0.05\%, pH 4.4 (Feder \& O’Brien 1968). In order to detect starch, the IKI reaction was performed (Johansen 1940). The analyses and photomicrographs under differential interference contrast (DIC) and bright field optical microscopy were performed under a Leica DMR Optical Microscope.

\section{Results}

The functional megaspore directly differentiates into a uninucleate gametophyte, increases its volume and form several small vacuoles (figure 1). The central nucleus undergoes mitosis and originates the binucleate gametophyte. The coalescence of the small vacuoles, forming a large central one, displaces these nuclei to the extremities of the young gametophyte (figure 2). The second mitotic cycle gives rise to a tetranucleate gametophyte (figure 3). At this stage, the gametophyte undergoes a growth and shape change phase, the micropylar extremity becomes rounded (figure 4), while the chalazal one is slender (figure 5), and the vacuole expands occupy most of the cell volume. During its growth, the gametophyte advances towards the micropyle and consumes the nucellar epidermis and the internal integument. After the third mitotic cycle, the octonucleated gametophyte presents four chalazal and four micropylar nuclei (not shown).

Three chalazal nuclei, after cellularization, establish a row of antipodals (figures 6,9 ) that degenerate later (figure 10). The last chalazal nucleus and its micropylar neighbour migrate to the median region of the central cell, and compose the two polar nuclei. These nuclei move together to the periphery of the central cell due the pressure of the large central vacuole (figures 6,8 ). During anthesis, the two polar nuclei migrate towards the egg apparatus and close to the egg cell, where they fuse shortly before fertilization, forming the diploid secondary nucleus (figure 15). The three remaining micropylar nuclei will form the egg apparatus. These cells present, initially, a triangular arrangement (figure 7).
During differentiation, they undergo vacuolation and show great polarity. The two pear-shaped synergids are disposed side by side, both with nucleus in the micropylar pole and a large vacuole in the chalazal side, and with cell wall specialization, to form the filiform apparatus, in the micropilar region (figure 13). The egg cell presents an inverse polarization, with the nucleus in the chalazal pole and the large vacuole in the micropylar pole (figure 14).

The nucellar cortex cells present large vacuoles, while the nucellar epidermis has denser more uniform cytoplasm (figure 10). The chalazal nucellar cells become elongated and give rise the hypostase (figure 11).

The mature gametophyte is composed of only four cells due the ephemeral nature of the antipodals. The gametophyte growth outwith the nucellar tissue and into the micropylar channel, is limited by the external integument on one side, and by the remaining nucellar cells and the hypostase on the other (figure 12). An accumulation of starch grains was observed in the central cell and in the synergids (figure 16).

Occasionally, more than one gametophyte was found to develop in the same ovule (figure 11). Although only one of them reached maturity, the other does not degenerate and can remain in the tetranucleate stage until fertilization (figure 12).

\section{Discussion}

The development monosporic Polygonum type of the female gametophyte recorded in Adesmia latifolia is the pathern described for most Leguminosae (Davis 1966, Prakash 1987). The other types, such as monosporic Oenothera type (Ojeaga \& Samyaolu 1970) and bisporic types (Guignard 1881, Rembert 1966, 1967, 1969) occur sporadically in legume tribes which are not phylogeneticaly related, except the deviations reported in some endemic australian species (Cameron \& Prakash 1994).

The function and behavior of the female gametophyte in the angiosperm reflect the integrated action of its cells (Jensen 1972). The egg and the synergids cells are close related and established the egg apparatus. In the angiosperms these cells may take on different shapes and sizes, but are generally pear-shaped cells (Raghavan 1997). The morphology and cytology of the egg apparatus cells of Adesmia latifolia gametophyte are the same described for other angiosperms. The egg cell is extremely polarized, with a large micropylar vacuole and an aggregate of 

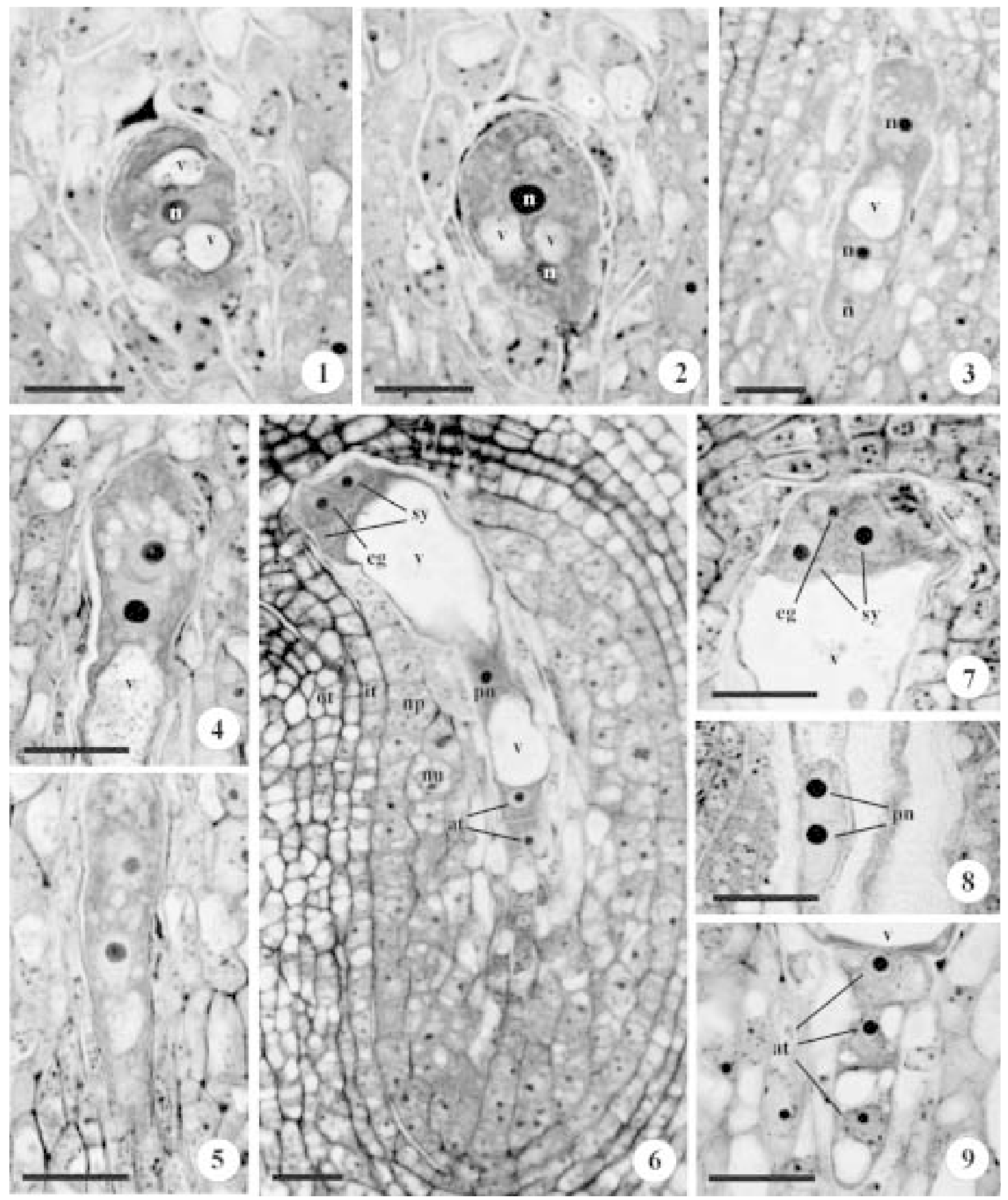

Figures 1-9. Photomicrographs of an ovule longitudinal section under bright field microscopy. 1. Uninucleate gametophyte with vacuoles at the poles and central nucleus. 2. Binucleate gametophyte with the nuclei at the poles and vacuoles at the center. 3. Initial stage of tetranucleate gametophyte, only one nuclei at the micropilar pole and two at the chalazal pole are visible. 4. Rounded micropylar extremity during the later stage of a tetranucleate gametophyte. 5. Slender chalazal extremity in the late stage of a tetranucleate gametophyte. 6. Arrangement of the seven cells in the gametophyte. 7. Detail of the pyramidal cells arrangement of the egg apparatus. 8. Detail of two polar nuclei very close to the peripheral central region of the central cells. 9. Detail of the antipodals in a row. at $=$ antipodals; it $=$ inner integument; $n=$ nucleus; $n p=$ nucellar epidermis; $\mathrm{nu}=$ nucellar cortex cells; eg = egg cell; ot = outer integument; $\mathrm{pn}=$ polar nucleus; $\mathrm{sy}=$ synergids; $\mathrm{v}=$ vacuole. Bars $=10 \mu \mathrm{m}$ $(1,2), 20 \mu \mathrm{m}(3-9)$. 


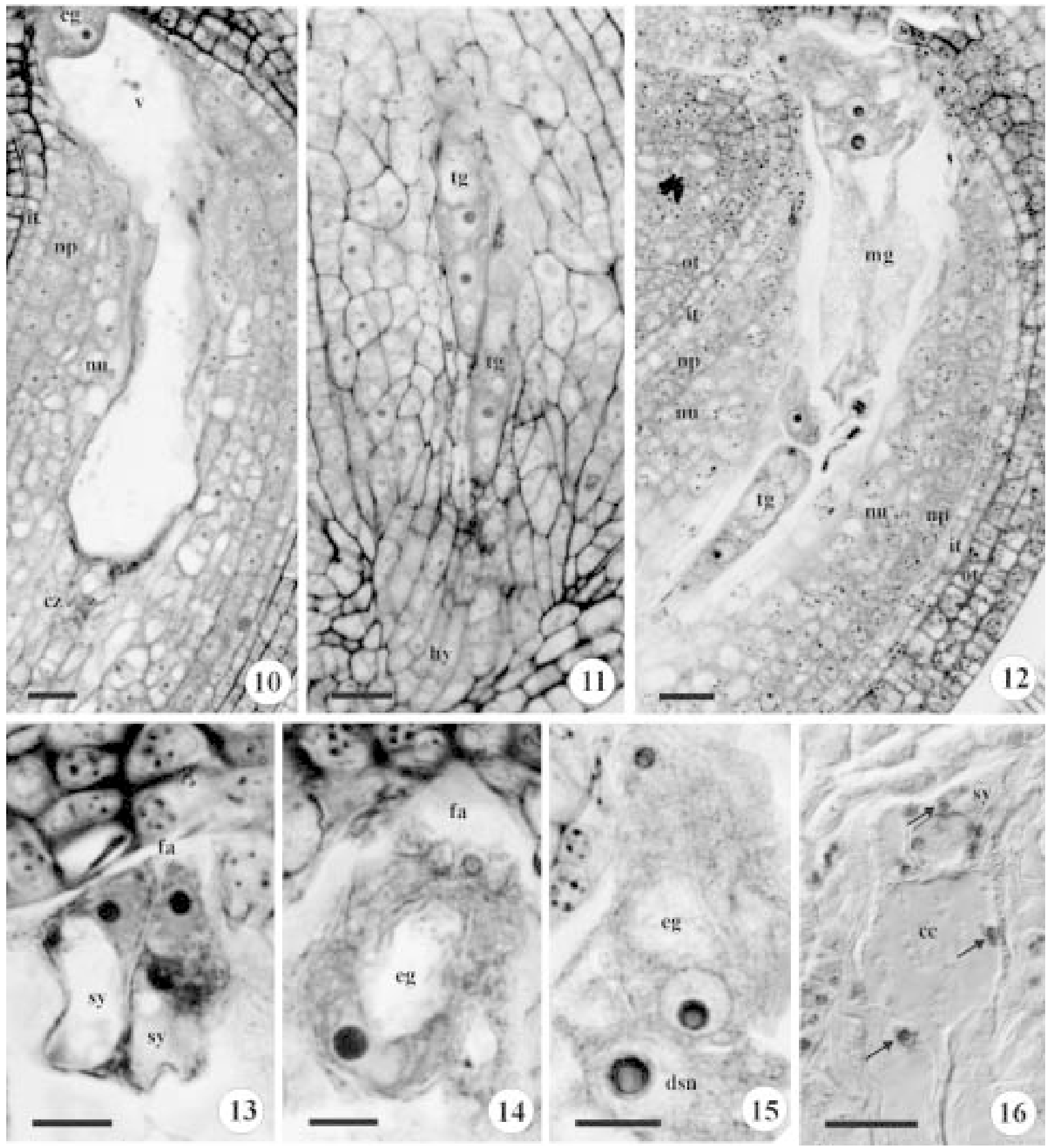

Figures 10-16. Photomicrographs of an ovule longitudinal section under bright field microscopy in figures 10 to 15 , and in differential interference contrast (DIC) in figure 16. 10. Mature gametophyte with degenerated antipodals in the chalazal region, vacuolated cortical nucellar cells, nucellar epidermal cells with dense cytoplasm. 11. Two tetranucleate gametophytes, only three nuclei at the chalazal pole are visible; the hypostase region in detail. 12. Two viable gametophytes during anthesis, one tetranucleate (chalazal) and another mature (micropylar). 13. Detail of the synergids with filiform apparatus. 14. Detail of the egg cell. 15. Detail of the diploid secondary nucleus near the egg cell, before fertilization. 16. Starch grains (arrows) in the synergids and central cell. $\mathrm{cc}=$ central cell; $\mathrm{cz}=$ chalaza; $\mathrm{dsn}=$ diploid secondary nucleus; fa $=$ filiform apparatus; hy $=$ hypostase; it = inner integument; $\mathrm{mg}=$ mature gametophyte; $\mathrm{np}=$ nucellar epidermis; $\mathrm{nu}=$ nucellar cortex cells; $\mathrm{eg}=\mathrm{egg}$ cell; ot = outer integument; sy = synergids; $\operatorname{tg}=$ tetranucleate gametophyte; $\mathrm{v}=$ vacuole. Bars $=20 \mu \mathrm{m}(10-12,16), 10 \mu \mathrm{m}(13-15)$. 
cytoplasmatic organelles, and the nucleus of the chalazal region. Raghavan (1997) suggested that this cell is quiescent due to its simplified ultrastructure with poor cytoplasmatic organization, whereas, the synergids present a large chalazal vacuole, nucleus and organelles in the micropylar region and a different ultrastructure, consistent with the interpretation that they would be responsible for a very active metabolism. This activity sign is also signalled by the storage of reserve products such as starch in these cells. The starch synthesis was recorded in the synergids of some species of Leguminosae such as Acacia baileyana F. Mueller (Newman 1934), Glycine max (L.) Merr. (Folsom \& Peterson 1984) and in Adesmia latifolia. However, it is unusual the starch storage in angiosperm egg cells, and has been recorded only in Gossypium, Capsella and Spinacia (Raghavan 1997).

Another important aspect of Adesmia latifolia synergids is the formation of a filiform apparatus in the walls next to the mycropyle. This structure is the result of an elaborate proliferation of wall material, which expands as small tubular fingerlike projections extending deep into the cytoplasm, making it easier to absorb and transport nutrients (Raghavan 1997). The presence of this wall specialization in A. latifolia synergids and in other Leguminosae species (Davis 1966, Prakash 1987) suggests an important role during fertilization, although in some cases the synergids degenerate before fertilization, as in Wisteria chinensis (Rembert 1967), and in others one there is no formation of filiform apparatus, such as in Crotalaria juncea L. (Samal 1946) and Tamarindus indica L. (Paul 1937).

The central cell has been considered as the biochemical maintainer, not only of the egg cell before fertilization, but also of the future zygotes (diploid and triploid) (Raghavan 1997, Chamberlin et al. 1993). The central cell expands and forms a large vacuole and functions as a storage area for carbohydrates, amino acids and inorganic salts. The presence of an elaborate cell wall with invaginations similar to those of the transfer cells in many species, as in Glycine max (Folsom \& Peterson 1984, Tilton et al. 1984, Folsom \& Cass 1986, Chamberlin et al. 1993) suggests that the central cell could be modified for absorption of nutrients from the neighboring nucellar cells, and for conversion into reserve products on a large scale. The nucellar cells around the gametophyte, as well as the nucellar epidermis and part of the integuments are consumed during growth, in many species of Leguminosae (Brown 1917, Martin 1914, Anantaswamy - Rau 1953, Prakash 1987), including Adesmia latifolia.
The accumulation of starch grains in the central cell is a feature of several angiosperms families (Willemse \& Went 1984, Raghavan 1997), and probably is associated with the embryo/endosperm metabolites supply during its first development phases (Folsom \& Peterson 1984, Kennel \& Horner 1985, Chamberlin et al. 1993). The occurrence of starch in central cell is recorded in Mimosoideae and Papilionoideae, but not in Caesalpinioideae (Davis 1966, Prakash 1987). In Arachis hypogaea L., the central cell is full of starch grains at maturity (Reed 1924, Smith 1956). Pattee \& Stalker (1991) compared the amount of starch stored in gametophytes of Arachis hypogaea with wild species and postulated that the variation in the quantity of starch could influence the success of embryos from interspecific hybridizations.

Several studies have shown that in most species of Leguminosae the fusion of the polar nuclei in the median region of the central cell (Prakash 1987, Ashrafunnisa \& Pullaiah 1994, 1999). In Melilotus, as in Adesmia latifolia, fusion only occurs near the egg apparatus, shortly before fertilization (Cooper 1933). In Trifolium alexandrinum L. (Krupko 1973), Medicago sativa L. (Martin 1914), Pisum sativum L. and Lathyrus sativus L. (Roy 1933), the polar nuclei approach the egg apparatus, but do not fuse.

Antipodal cells morphology has not been used as a gametophyte parameter due to their great variability in the number, life span, cytology, growth and structure (Raghavan 1997). The behavior of the antipodals after cellularization in the species of Leguminosae is also variable. They are disposed in a row in Adesmia latifolia, as in Dichrostachys cinerea (L.) Wight \& Arn. and Parkia biglandulosa Wight \& Arn. (Dnyansagar 1954), Prosopis spicigera L. and Desmanthus virgatus (L.) Willd. (Dnyansagar 1957), Phaseolus aconitifolius Jacq. (Deshpande \& Bhasin 1974). In Millettia ovalifolia Kurz. (Pal 1960) the antipodals may be arranged side by side, in a pyramid or inverted pyramid. The antipodals are persistent, at least until fertilization, in the subfamilies Mimosoideae and Caesalpinioideae (Prakash 1987, Johri et al. 1992), except in Parkinsonia (Davis 1966) and Cassia mimosoides L. (Johri et al. 1992). In most of the Papilionoideae species studied, including Adesmia latifolia, the antipodals are ephemeral. However, there is a record of persistent antipodals in Medicago sativa (Martin 1914), Pachyrhizus (Roy 1933), Pisum sativum (Cooper 1938), Millettia ovalifolia (Pal 1960), Lespedeza juncea (L.f.) Pers., and Lotus cruentus A.B. Court (Cameron \& Prakash 1990). Giant 
antipodals were recorded in some species of the Mirbelieae, Bossiaeeae and Indigofereae tribes (Cameron \& Prakash 1990, 1994).

Little attention has been given to the functional relationships of antipodals. Some authors suggest a nutritional behaviour in the gametophyte (Raghavan 1997, Reiser \& Fischer 1993, Cameron \& Prakash 1990, 1994), although the loss of the antipodals in Glycine max gametophytes was possibly being compensated by the production of a large amount of starch and lipids in the central cell (Tilton et al. 1984).

Various cytological changes have been recorded in the nucellar cells of ovules in the Leguminosae during gametophyte growth (Rangan \& Rangaswamy 1999). Samal (1936) observed in Crotalaria juncea that the nucellar cells, close to the gametophyte, presented two nuclei. In others Papilionoideae species remnants of nucellar epidermis remain in the micropylar region as a protective cap, as in Desmodium gangeticum (L.) W. \& A. (Pantulu 1942), Milletia ovalifolia (Pal 1960), Trifolium pratense L. (Hindmarsh 1964), T. repens L. (Rembert 1977), Indigofera enneaphylla L. (Deshpande \& Untawale 1971), Arachis hypogaea (Periasamy \& Sampoornam 1984), and Psophocarpus tetragonolobus (L.) DC. (Lim \& Prakash 1994).

However, in Phaseolus species and Adesmia latifolia the gametophyte presents aggressive growth towards the micropylar channel and consumes part of the parietal nucellar cells and the nucellar epidermis. In A. latifolia the gametophyte consumes part of the inner integument, but cortical nucellar cells persist around it, while in Phaseolus the cortical nucellar cells are also almost completely consumed and only a few cells of the nucellar epidermis remain in the chalazal region (Deshpande \& Bhasin 1974).

The similarity between the nucellar epidermis and an endothelium was stressed by Periasamy \& Sampoornam (1984) in Arachis hypogaea and by Deshpande \& Bhasin (1974), in Phaseolus. The term endothelium refers to type of the integumentary layer, which is in direct contact with the gametophyte and has the function of transferring nutrients or the secretion of enzymes such as amylases and proteases (Bouman 1984). This true endothelium occurs in Trifolium pratense (Hindmarsh 1964), Glycine javanica L., Clitoria ternatea L., and species of Tephrosia (Anantaswamy Rau 1951). It is likely that, in Phaseolus and in Arachis, there has been a transfer of function from the integumentary endothelium to the nucellar epidermis. Similar cytological differences between the cells of the nucellar epidermis and the remaining neighboring nucellar cells, found in Adesmia latifolia in the present study, were also observed by Deshpande \& Bhasin (1976) in Zornia diphylla (L.) Pers. These authors also suggested that the nucellar epidermis in the latter species would be analogous to an endothelium. However, in A. latifolia and Z. diphylla the cytological characteristics do not justify this analogy because the epidermis is not in direct contact with the gametophyte.

The hypostase is a well-defined group of nucellar cells, adjacent to the gametophyte chalazal region (Shamrov 1998, Batygina \& Shamrov 1999, Rangan \& Rangaswamy 1999). In the Leguminosae family, the hypostase is recorded in Adesmia latifolia, and also in Glycine max and Phaseolus aureus Roxb. (George et al. 1979); in Wisteria chinensis (Rembert 1967); in Medicago sativa (Reeves 1930); and Phaseolus vulgaris (Brown 1917). The main function of this structure may be the translocation of nutrients, from the placenta and vascular bundle to the integuments and to the gametophyte (Shamrov 1998, Batygina \& Shamrov 1999, Rangan \& Rangaswamy 1999).

The presence of two female gametophytes, which remain viable until fertilization, as found in Adesmia latifolia, is rare in the Leguminosae family. In Medicago sativa more than one developing megaspore was found, but one of them still degenerated at binucleate stage (Martin 1914, Reeves 1930). In Acacia baileyana occasionally two gametophytes were recorded, but one always degenerates (Newman 1934). Hindmarsh (1964) also recorded this but suggested that they could be apomytic. However, the formation of multiple gametophytes is common in Australian species with have a gametophyte development of the Mirbelia and Jacksonia type (Cameron \& Prakash 1994).

The development of more than one gametophyte per ovule is rare in angiosperms (Maheshwari, 1950). In some species of the Rubieae (Rubiaceae) (Mariath \& Cocucci 1997), for example, the occurrence of alternative gametophytes in different development stages may be a reproductive strategy to increases the chances of fertilization if the former (close to the micropyle) has not been fertilized. This aspect of the reproductive biology must be investigated in Adesmia latifolia.

Some features of the development of the female gametophyte recorded in this study may be taxonomically important for the tribe Adesmieae, such as ephemeral antipodals, fusion of polar nuclei before fertilization, storage of starch in the central cell and in the synergids, and formation of the filiform apparatus in the synergids. It is also notable that the general aspect of the ovules of 
Adesmia latifolia in the mature gametophyte stage is similar to that of Zornia diphylla of the tribe Aeschynomeneae. This observation corroborates the phylogenetic analysis that indicates a relationship between the tribes Aeschynomeneae and Adesmieae (Lavin et al. 2001).

Acknowledgements - We would like to thank CNPq for doctoral degree and research grants for first and second authors, respectively, and the FAPERGS for their financial support. To the director and technicians of the Electron Microscopy Center at the Federal University of Rio Grande do Sul (CME/UFRGS) for the use of equipment. To the employees in the Agronomic Station of UFRGS and to Bibiana Cassol, technician in the Plant Anatomy Laboratory, Department of Botany/UFRGS, for their help during field collection and preparation of the material in the laboratory, respectively.

\section{References}

ANANTASWAMY RAU, M. 1951, The endosperm in some of the Papilionaceae. Phytomorphology 1:153-158.

ANANTASWAMY RAU, M. 1953. Some observations on the endosperm in Papilionaceae. Phytomorphology 3:209-222.

ASHRAFUNNISA \& PULLAIAH, T. 1994. Embryology of Galactia (Fabaceae). Phytomorphology 44:253-260.

ASHRAFUNNISA \& PULLAIAH, T. 1999. Embryology of Teramnus labialis (Fabaceae). Phytomorphology 49:192-202.

BATYGINA, T.B. \& SHAMROV, I.I. 1999. New approach to interpreting the ovular basic structures. Phytomorphology 49:223-231.

BOUMAN, F. 1984. The ovule. In Embryology of Angiosperms (B.M. Johri, ed.). Springer-Verlag, Berlin, p.123-157.

BROWN, M.M. 1917. The development of the embryo-sac and of the embryo in Phaseolus vulgaris. Bulletin of the Torrey Botanical Club 44:535-544, pl. 25-26.

CAMERON, B. \& PRAKASH, N. 1990. Occurrence of giant antipodals in the female gametophytes of Australian Bossiaeeae, Indigofereae and Mirbelieae (Leguminosae). Australian Journal of Botany 38:395-401.

CAMERON, B. \& PRAKASH, N. 1994. Variations of megagametophyte in Papilionoideae. In Advances in Legume Systematics 6: Structural Botany (I.K. Ferguson \& S. Tucker, eds.). Royal Botanic Gardens, Kew, p.97-115.

CHAMBERLIN, M.A., HORNER, H.T. \& PALMER, R.G. 1993. Nutrition of ovule, embryo sac, and yong embryo in soybean: na anatomical and autoradiographic study. Canadian Journal of Botany 71:1153-1168.

COOPER, D.C. 1933. Macrosporogenesis and embryology of Melilotus. Botanical Gazette 95:143-155.
COOPER, D.C. 1938. Embryology of Pisum sativum. Botanical Gazette 100:123-132.

DAVIS, O.L. 1966. Systematic embryology of the Angiosperms. John Wiley \& Sons, New York.

DESHPANDE, P.K. \& BHASIN, R.K. 1974. Embryological studies in Phaseolus aconitiifolius Jacq. Botanical Gazette 135:104-113.

DESHPANDE, P.K. \& BHASIN, R.K. 1976. A contribution to the life history of Zornia diphylla Pers. Journal of the Indian Botanical Society 55:115-124.

DESPHANDE, P.K. \& UNTAWALE, A.G. 1971. Development of the seed and fruit in Indigofera enneaphylla L. Botanical Gazette 132:96-102.

DNYANSAGAR, V.R. 1954. Embryologycal studies in the Leguminosae. VI. Inflorescence sporogenesis and gametophyte of Dichrostachys cinerea and Parkia biglandulosa. Lloydia 17:263-274.

DNYANSAGAR, V.R. 1957. Embryological studies in the Leguminosae. V. Prosopis spicigera and Desmanthus virgatus. Botanical Gazette 118:180-186.

FEDER, N. \& O'BRIEN, T.P. 1968. Plant microthechnique: some principles and new methods. American Journal of Botany 55:123-142.

FOLSOM, M.W. \& CASS, D.D. 1986. Changes in transfer cell distribution in the ovule of soybean after fertilization. Canadian Journal of Botany 64:965-972.

FOLSOM, M.W. \& PETERSON, C.M. 1984. Ultrastructural aspects of the mature embryo sac of soybean, Glycine $\max ($ L.) Merr. Botanical Gazette 145:1-10.

GEORGE, G.P., GEORGE, R.A. \& HERR JUNIOR, J.M. 1979. A comparative study of ovule and megagametophyte development in field-grown and greenhouse-grown plants of Glycine max and Phaseolus aureus (Papilionaceae). American Journal of Botany 66:1033-1043.

GERRITS, P.O. \& SMID, L. 1983. A new, less toxic polymerization system for the embedding of soft tissues in glycol methacrylate and subsequent preparing of serial sections. Journal of Microscopy 132:81-85

GUIGNARD, L. 1881. Recherches d'embryogénie végétale comparée. 1. Legumineuses. Annales Des Sciences Naturelles-Botanique 12:5-166.

HAIG, D. 1990. New perspectives on the Angiosperm female gametophyte. The Botanical Review 56:236-274.

HINDMARSH, G.J. 1964. Gametophyte development in Trifolium pratense L. Australian Journal of Botany 12:1-14.

JENSEN, W.A. 1972. The embryo sac and fertilization in angiosperms. University of Hawaii Harold L. Lyon Arboretum Lecture Number Three, p.3-31.

JOHANSEN, D.A. 1940. Plant Microtechnique. McGraw-Hill, New York.

JOHRI, B.M., AMBEGAOKAR, K.B. \& SRIVASTAVA, P.S. 1992. Comparative embryology of Angiosperms. Springer-Verlag, Berlin. 
KENNELL, J. \& HORNER, H.T. 1985. Megasporogenesis and megagametogenesis in soybean, Glycine max. American Journal of Botany 72:1553-1564.

KRUPKO, S. 1973. Megasporogenesis and development of the embryo sac in the Palestine variety of Trifolium alexandrinum L. Acta Societatis Botanicorum Poloniae 42:617-625.

LAVIN, M., PENNINGTON, T., KLITGAARD, B.B., SPRENT, J.I., LIMA, H.C. \& GASSON, P.E. 2001. The dalbergioid legumes (Fabaceae): delimitation of a pantropical monophyletic clade. American Journal of Botany 88:503-533.

LIM, A.L. \& PRAKASH, N. 1994. Embryology and seed development in the winged bean, Psophocarpus tetragonolobus. Gardens' Bulletin 46:79-92.

MAHESHWARI, P. 1950. An introduction to the embryology of Angiosperms. $5^{\text {th }}$ reprint, McGraw-Hill, New Delhi.

MARIATH, J.E.A. \& COCUCCI, A.E. 1997. The ovules of Relbunium hypocarpium in the context of the Rubiaceae. Kurtziana 25:141-150.

MARTIN, J.N. 1914. Compartive morphology of some Leguminosae. Botanical Gazette 58:154-167.

MCDOWELL, E.M. \& TRUMP, B. 1976. Histological fixatives for diagnostic light and eletron microscopy. Archives of Pathology \& Laboratory Medicine 100:405-414.

MOÇO, M.C.C. \& MARIATH, J.E.A. 2003. Ovule ontogenesis and megasporogenesis in Adesmia latifolia (Spreng.) Vog. (Leguminosae-Papilionoideae). Revista Brasileira de Botânica 26:495-502.

NEWMAN, I.V. 1934. Studies in the australian acacias. IV. The life history of Acacia baileyana F.V.M. Proceedings of Linnean Society of the New South Wales 59:277-315.

OJEAGA, O. \& SANYAOLU, M.O. 1970. Ovule formation and embryo development in persisting and abortive fruits of the cowpea Vigna unguiculata. Nigerian Journal of Science 4:31-40.

PAL, N. 1960. Development of the seed of Milletia ovalifolia. Botanical Gazette 122:130-137.

PANTULU, J.V. 1942. A contribution to the life history of Desmodium gangeticum. Journal of Indian Botanical Society 21:137-144.

PATTEE, H.E. \& STALKER, H.T. 1991. Comparative embryo sac morphology at anthesis of cultivated and wild species of Arachis. Annals of Botany 68:511-517.

PAUL, A.K. 1937. Development of the ovule and embryo sac of Tamarindus indica L. Journal of the Indian Botanical Society 16:151-157.
PERIASAMY, K. \& SAMPOORNAM, C. 1984. The morphology and anatomy of the ovule and fruit development in Arachis hypogaea L. Annals of Botany 53:399-411.

PRAKASH, N. 1987. Embryology of the Leguminosae. In Advances in Legume Systematics 3 (C.H. Stirton, ed.). Royal Botanic Gardens, Kew, p.241-278.

RAGHAVAN, V. 1997. Molecular embryology of flowering plants. Cambridge University Press, Cambridge.

RANGAN, T.S. \& RANGANSWAMY, N.S. 1999. Nucellus a unique embryologic system. Phytomorphology 49:337376.

REED, E.L. 1924. Anatomy, embryology and ecology of Arachis hypogaea. Botanical Gazette 78:289-310.

REEVES, R.G. 1930. Development of the ovule and embryo sac of alfalfa. American Journal of Botany 17:239-246.

REISER, L. \& FISHER, R.L. 1993. The ovule and the embryo sac. The Plant Cell 5:1291-1301.

REMBERT JUNIOR, D.H. 1966. Megasporogenesis in Laburnum anagyroides Medic.- a case of bisporic development in Leguminosae. Transactions of the Kentucky Academy of Science 27:47-50.

REMBERT JUNIOR, D.H. 1967. Development of the ovule and megagametophyte in Wisteria chinensis. Botanical Gazette 128:223-229.

REMBERT JUNIOR, D.H. 1969. Comparative megasporogenesis in Papilionaceae. American Journal of Botany 56:584-591.

REMBERT JUNIOR, D.H. 1977. Ovule ontogeny, megasporogenesis and early gametogenesis in Trifolium repens (Papilionaceae). American Journal of Botany 64:483-488.

ROY, B. 1933. Studies in the development of the female gametophyte in some leguminous crops of India. Indian Journal of Agriculture and Science 3:1098-1107.

SAMAL, K.K. 1936. The development of the embryo sac and embryo in Crotalaria juncea. Journal of the Indian Botanical Society 15:19-31.

SHAMROV, I.I. 1998. Ovule classification in flowering plantsnew approaches and concepts. Botanische Jahrbürcher für Systematik 120:307-407.

SMITH, B.W. 1956. Arachis hypogaea: normal megasporogenesis and syngamy with occasional single fertilization. American Journal of Botany 43:81-89.

TILTON, V.R., WILCOX, L.W. \& PALMER, R.G. 1984. Postfertilization wandlabrinthe formation and function in the central cell of soybean, Glycine $\max$ (L.) Merr. (Leguminosae). Botanical Gazette 145:334-339.

WILLEMSE, M.T.M. \& VAN WENT, J.L. 1984. The female gametophyte. In Embryology of Angiosperms (B.M. Johri, ed.). Springer-Verlag, Berlin, p.159-196. 